\title{
Genetic Variability Analysis among Clinical Candida spp. Isolates Using Random Amplified Polymorphic DNA
}

\author{
Patrícia M Pinto/+ , Maria A Resende, Cristiane Y Koga-Ito**, Miriam Tendler*
}

Departamento de Microbiologia, Instituto de Ciências Biológicas, Universidade Federal de Minas Gerais, Av. Antonio Carlos 6627, 31270-901 Belo Horizonte, MG, Brasil *Departamento de Helmintologia, Instituto Oswaldo Cruz-Fiocruz, Rio de Janeiro, RJ, Brasil **Departamento de Biociências e Diagnóstico Bucal, Faculdade de Odontologia de São José dos Campos, Unesp, São José dos Campos, SP, Brasil

The patterns of genetic variation of samples of Candida spp. isolated from patients infected with human immunodeficiency virus in Vitória, state of Espírito Santo, Brazil, were examined. Thirty-seven strains were isolated from different anatomical sites obtained from different infection episodes of 11 patients infected with the human immunodeficiency virus (HIV). These samples were subjected to randomly amplified polymorphic DNA (RAPD) analysis using 9 different primers. Reproducible and complex DNA banding patterns were obtained. The experiments indicated evidence of dynamic process of yeast colonization in HIV-infected patients, and also that certain primers are efficient in the identification of species of the Candida genus. Thus, we conclude that RAPD analysis may be useful in providing genotypic characters for Candida species typing in epidemiological investigations, and also for the rapid identification of pathogenic fungi.

Key words: polymerase chain reaction - random amplified polymorphic DNA - candidosis - Candida spp.

Several reports have described a significant increase in the incidence of systemic candidosis during the last decade (Hazen 1995, Voss et al. 1995, Coleman et al. 1997). The increase of the immune-suppressed population specially related to the human immunodeficiency virus (HIV), organ transplantation, and chemotherapy had dramatically raised the incidence of candidosis (Klein et al. 1984, Odds 1988, Samaranayake \& Holmstrup 1989, Odds et al. 1990, Coleman et al. 1993, Pfaller 1995). Oropharingeal candidosis, caused mainly by the commensal yeast Candida albicans, is the most frequently occurring opportunistic infection, during acquired immunodeficiency syndrome (AIDS). Up to $90 \%$ of individuals infected with the HIV have presented at least one episode of oropharyngeal candidosis during the course of their disease (Klein et al. 1984, Barchiesi et al. 1997). C. albicans is the most pathogenic species of the Candida genus and the most frequently associated with candidosis (Odds et al. 1990). Earlier studies on the epidemiology of candidiasis used phenotypic properties to assess strain identity, but these methods lacked resolution power (Merz 1990, Pfaller et al. 1990). With the advent of molecular genetics more powerful DNA-based typing methods have emerged for clinical and epidemiological analysis (Scher \& Stevens 1988,

This study was approved by the Ethic Commitee of the Federal University of Minas Gerais, process ETIC 061/02.

Financial support: $\mathrm{CNPq}$

${ }^{+}$Corresponding author. Fax: +55-21-2260.4866. E-mail: pmpinto@ioc.fiocruz.br

Received 23 September 2003

Accepted 1 March 2004
Schmid et al. 1990, Stevens et al. 1990, Clemons et al. 1997, Corlotti et al. 1997, Diaz-Guerra et al. 1997, Meyer et al. 1997, Xu et al. 1999b). These include fingerprinting methods such as karyotyping using pulse-field electrophoresis (PFGE), restriction fragment length polymorphism (RFLP), randomly amplified polymorphic DNA analysis (RAPD), and Southern hybridization with moderately repetitive DNA probes (Odds et al. 1992, Espinel-Ingroff et al. 1999). These methods have been used extensively for the detection and typing of Candida strains (Heimdahl \& Nord 1990, Clemons et al. 1991, Bart-Delabesse et al. 1993, Miyakawa et al. 1993, Holmes et al. 1994) but have been used less frequently for differentiation of species. The most frequently used PCR-based technique currently in use is RAPD. In this technique, single or a pair wise combination of primers, typically 9 to 10 nucleotides in length, are used to amplify target genomic DNA by polymerase chain reaction (PCR). Fragments of DNA are generated by PCR amplification if the primer target sites for the primer happen to occur within approximately $5 \mathrm{~kb}$ of each other on opposite DNA strands. The amplified products form strain-specific fingerprints are then analyzed by separation through an agarose gel and ethidium bromide stained (Welsh \& McClelland 1990). This procedure seemed to be efficient in distinguishing different isolates; it has a high discriminatory power, it is easy to perform, does not require radiolabelled probes, and it is applicable to several microorganisms (Robert et al. 1995).

The aims of this work were to identify the species of the genus Candida and to analyze the genetic variability intra and inter-specific of 37 strains isolated from different anatomical sites of 11 immune-compromised patients infected with HIV, through the RAPD assay. Additionally, molecular biology techniques have been used to highlight information about genomic structure of these microorganisms and the epidemiology of the candidosis. 


\section{MATERIALS AND METHODS}

Isolates - Thirty-seven strains were isolated from 11 immune-compromised patients infected by HIV, from Vitória, ES, Brazil. These samples were obtained through oropharingeal swabs, brushed from esophagus, and esophagus biopsy. The collection of the sample was performed with the aid of sterile swabs or citology brush during the endoscopic examinations (Table). All isolates were identified through tests of germ tube formation, fermentation, and assimilation of distinct carbohydrate and also through micro-morphological characterization (Kreger-Van Rij 1984, Kurtzman \& Fell 1998). All the strains were maintained at $4^{\circ} \mathrm{C}$ on Sabouraud dextrose agar (SDA) until identification tests were carried out. Transfers were done at 3-month intervals. The isolate of C. albicans, ATCC 18804 was included in this study.

DNA extraction - The DNA was extracted from all the isolates by the method described by Caligiorne et al. (1999) with modifications. The samples were grown on Sabouraud dextrose agar overnight at $37^{\circ} \mathrm{C}$ and a few colonies were transferred to a $1.5 \mathrm{ml}$ Eppendorf tube containing $1 \mathrm{ml}$ of $0.85 \% \mathrm{NaCl}$ solution. Then, the pellets were recovered by centrifugation $10,000 \mathrm{Xg}$ for $15 \mathrm{~min}$ at $4^{\circ} \mathrm{C}$ and resuspended in $0.1 \mathrm{M}$ Citrate, 1.1 M Sorbitol, and incubated with $3 \mathrm{mg} / \mathrm{ml}$ Glucanex (Glucanase/Novo Nordisk do Brasil, RS) for $3 \mathrm{~h}$ at $37^{\circ} \mathrm{C}$ so that the cellular walls were disrupted. After centrifugation, the precipitate was re-suspended in lysis buffer $0.04 \mathrm{M}$ Tris ( $\mathrm{pH}$ 8.5), 0.20 $\mathrm{M} \mathrm{NaCl}, 1.5 \%$ sarcosil and $0.01 \mathrm{M}$ EDTA $0.5 \mathrm{M}$ (pH 8.0). Then, pellets were washed three times with phenol-chloroform and then precipitated with ethanol absolute and $0.3 \mathrm{M} \mathrm{NaCl}$. After $15 \mathrm{~min}$, the precipitate was centrifuged and washed twice with $70 \%$ ethanol dried and re-suspended in $50 \mu \mathrm{l}$ of $10 \mathrm{mM}$ Tris- $\mathrm{HCl}(\mathrm{pH} 7.5)$.

$R A P D$ reactions - Each amplification was done in a final volume of $10 \mu$ l containing $1 \mathrm{X}$ buffer (Promega), 0.2 $\mathrm{mM}$ each of dATP, dGTP, dCTP, and dTTP (Promega), 1 ng of genomic-DNA, $2 \mathrm{mM}$ of $\mathrm{MgCl}_{2}$ (Promega), $0.8 \mu \mathrm{M}$ of primer (Operon), and one unit of thermostable Taq DNA polymerase (Promega).

Amplification parameters consisted of 35 cycles of denaturation at $95^{\circ} \mathrm{C}$ for $60 \mathrm{~s}$, primer annealing at $36^{\circ} \mathrm{C}$ for $60 \mathrm{~s}$ and extension at $72^{\circ} \mathrm{C}$ for $60 \mathrm{~s}$. In the first cycle, denaturation was done for $3 \mathrm{~min}$ and in the last cycle, final extension lasted for $5 \mathrm{~min}$. Reactions were carried out using primers from Operon OPA 01 (CAGGCCCTTC), OPA 02 (TGCCGAGCTG), OPA 03 (AGTCAGCCAG), OPA 08 (GTGACGTAGG), OPA09 (GGGTAACGCC) as well as SOY (AGGTCACTGA), RP1-4 (TAGGATCAGA), RP-2 (AAGGATCAGA) and RP4-2 (CACATGCTTC) primers (Lehmann et al. 1992).

Polyacrylamide gel electrophoresis - Following the amplification, $3 \mu \mathrm{l}$ of the reaction was mixed with DNA sample buffer $(0.125 \%$ xylene cyanol, $0.125 \%$ bromophenol blue, $15 \%$ glycerol) and subjected to electrophoresis through a $6 \%$ polyacrylamide gel (acrylamide-bisacrylamide 29/1) in TBE buffer ( 2 mM EDTA, 10 mM Trisborate, $\mathrm{pH}$ 8.0). The gels were silver stained by the method described by Santos et al. (1993).

For each experiment, the sizes of DNA fragments am- plified by PCR were determined by direct comparison with the DNA marker (100 bp Ladder, Gibco, BRL).

\section{RESULTS}

All the 37 isolates studied were phenotypically identified (Kreger-Van Rij 1984, Kurtzman \& Fell 1998). The identification of these samples was confirmed through the assimilation test of several carbohydrate sources.

Among the 37 Candida isolates obtained from the 11 immune-compromised patients infected with HIV in the state of Espírito Santo, C. albicans was the most frequently isolated species (94.6\%), followed by $C$. guilliermondii (5.4\%).

In order to examine genomic variability among the Candida isolates, molecular analysis was undertaken using RAPDs generated by 9 primers, OPA 01 , OPA 02 , OPA 03, OPA 08, OPA 09 as well as SOY, RP1-4, RP-2, and RP42. Fig. 1 a, b, c, d show the RAPD profiles of 37 isolates, amplified with primer OPA 09, from patients infected with HIV. Fig. 1a shows the 3 isolates of patient A, 4 isolates of the patient $\mathrm{B}$, and 3 isolates of patient $\mathrm{C}$, respectively. RAPD profiles of the same patient were similar, but not identical, whereas the profiles of different patients showed higher levels of polymorphisms. Fig. 1b shows the amplifications of 9 isolates from the patient $\mathrm{D}$ and 2 isolated of the patient E. Patient D presented 2 species, C. albicans and $C$. guilliermondii that were obtained from different infection episodes. During the first episode only C. albicans was isolated, but interestingly in a second episode an association between $C$. albicans and $C$. guilliermondii was observed (Table). The samples D 15 and D 16 were isolated from oral swabs, 10 and 16 days respectively after the first infection (Table). Isolate D 12 (biopsy), D 13 (brushed), and D 14 (swab) present a homogeneous profile, different from isolate D 19 collected 16 days after the first infection. The polymorphisms observed in isolate D 19 indicates that in the second episode the patient was infected with a genetically distinct isolate. Isolate D 18 also obtained from the second infection presented the same genotype of the first infection. In the second infection patient D was also infected with $C$. guiilliermondii, (D 11, D 17). Intra-specific polymorphisms were not observed between these isolates. Fig. 1c shows the profiles obtained for 5 isolates from patient F, 2 isolates from patient $\mathrm{G}$ and 2 isolates from patient $\mathrm{H}$ respectively. Isolates F 24 and F 25 were obtained from a first infection and isolates F 22, F 23, F 26 were obtained from a second infection (Table). In the second infection, 2 distinct genotypes were observed. One isolate was obtained through oropharingeal swab (F 23) and others from esophagus brushed and esophagus biopsy (F 22, F 26). RAPD profiles of isolates from the patients $\mathrm{G}$ and $\mathrm{H}$ were similar, but not identical. The profiles of the isolates from the same patient showed higher levels of similarity. Fig. 1 $d$ shows the amplifications of 3 isolates from the patient $I$, 2 isolates from patient $\mathrm{J}$, and 2 isolates from patient $\mathrm{K}$. We can observe that profiles obtained for the isolates from the same patient were more homogeneous when compared with the inter-individual profiles. Fig. 2 shows the analysis of RAPDs derived from patients D and E samples obtained with primer OPA 02 . The results obtained for primer OPA 09 were similar to those observed for primer OPA 02. 
a

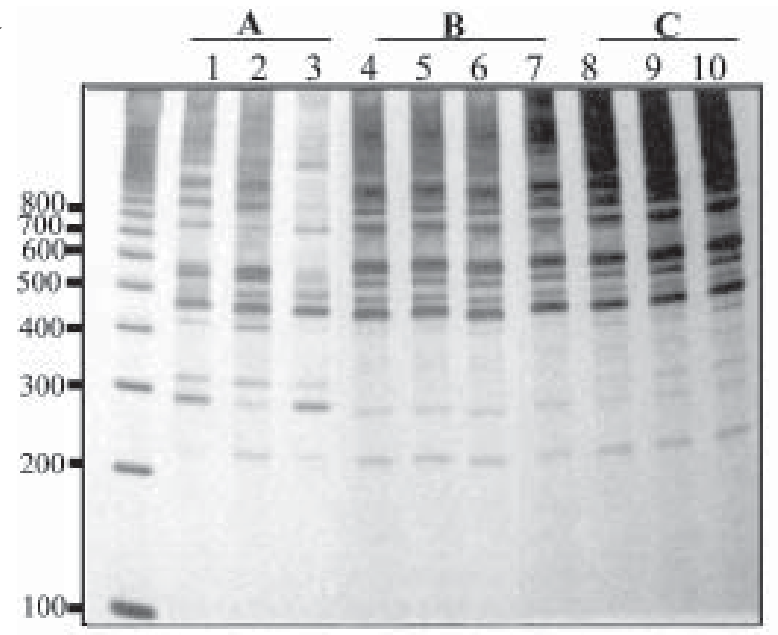

b
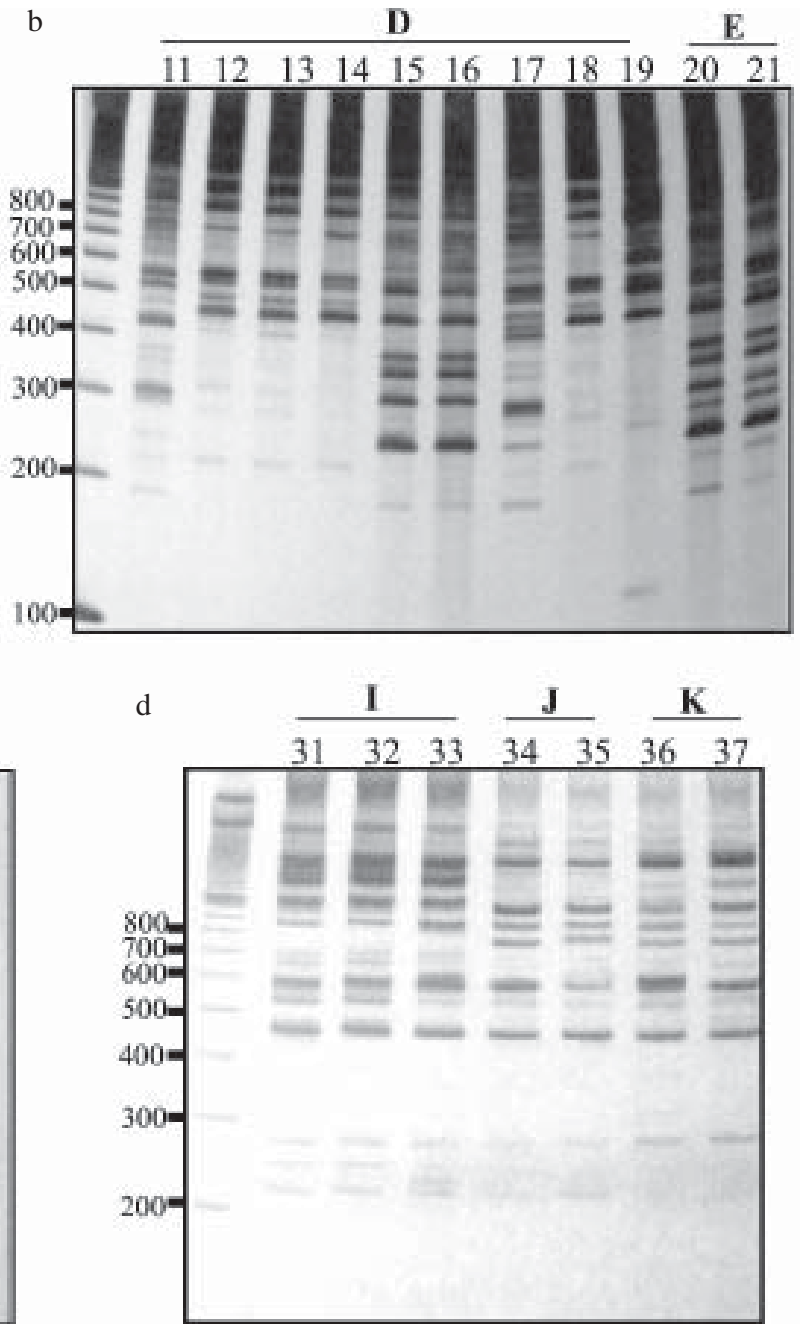

c

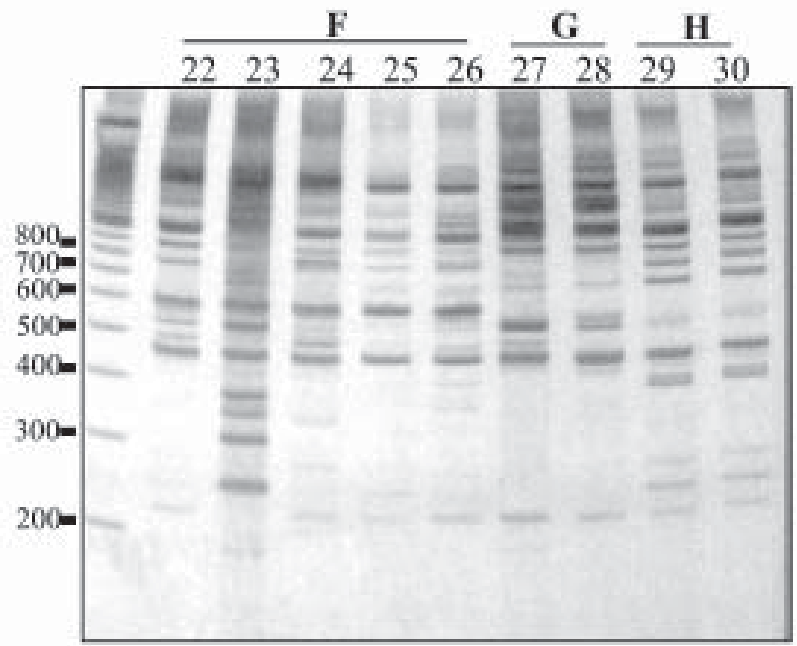

Fig. 1: randomly amplified polymorphic DNA profiles of 37 isolates from patients infected with human immunodeficiency virus, using 1 ng of template and primer OPA 09. a: analysis of 3 isolates from patient A (1-3), 4 isolates from patient B (4-7), and 3 isolates from patient $\mathrm{C}(8-10)$; b: analysis of 9 isolates from patient D (11-19) and 2 isolated from patient E (20-21); c: analysis of 5 isolates from patient $\mathrm{F}$ (22-26), 2 isolates from patient G (27-28), and 2 isolates from patient $\mathrm{H}$ (29-30); d: analysis of 3 isolates from patient I (31-33), 2 isolates from patient $\mathbf{J}$ (34-35), and 2 isolates from patient $\mathrm{K}$ (36-37). The polymerase chain reaction products were resolved by electrophoresis on a $6 \%$ polyacrylamide gel followed by silver staining.

The same was observed with the other samples (data not shown). Some primers were not capable to differentiate the genotypes of different isolates of the genus Candida. Fig. 3 a, b shows the profile of RAPD of the same samples of patients D and E obtained with the primers OPA 03 and SOY. We can observe the presence of a single genotype among all the isolates, obtained with both primers. However, we can observe that these primers were efficient in the identification of the species (D 11, D 17). The other primers generated results similar to the primers OPA 02 and OPA 09.

All the $C$. albicans isolates studied showed an amplification profile similar to the strain ATCC 18804 (data not shown).

We can conclude that some primers were efficient in the identification of species of the genus Candida and others were useful in the identification of inter-specific genotypes.

\section{DISCUSSION}

Oropharyngeal candidosis is the most common opportunistic infection during AIDS. It is associated with pain, limits food ingestion and can lead to cachexia (Cameron et al. 1993). With the increasing number of immune-compromised patients, such as infected-HIV patients, or those living together in the same environment in hospital wards, inter-human transmission of pathogenic fungi is likely to occur frequently. However, it is a rare event and has only recently been demonstrated by molecular typing methods for nosocomial Candida infections in patients at risk for candidosis (Romano et al. 1994, Bart-Delabesse et al. 1995, Voss et al. 1995).

Molecular analysis was undertaken using RAPDs generated by 9 primers. This technique enables a large number of independent genetic loci to be examined that are not based on particular sequences or types of sequences 
TABLE

Origin of the 37 isolates from different anatomical sites in 11 immune-suppresed patients infected by human immunodeficiency virus (Vitória, ES)

\begin{tabular}{|c|c|c|c|}
\hline Patients & $\begin{array}{c}\text { Isolate } \\
\text { designation }\end{array}$ & Body site & Data of isolation $(\mathrm{m} / \mathrm{d} / \mathrm{y})$ \\
\hline 1 & $\begin{array}{l}\text { A } 01 \\
\text { A } 02 \\
\text { A } 03\end{array}$ & $\begin{array}{l}\text { Esophagus biopsy } \\
\text { Brushed esophagus } \\
\text { Oral cavity (swab) }\end{array}$ & $\begin{array}{l}04 / 28 / 99 \\
04 / 28 / 99 \\
04 / 30 / 99\end{array}$ \\
\hline 2 & $\begin{array}{l}\text { B } 04 \\
\text { В } 05 \\
\text { В } 06 \\
\text { В } 07\end{array}$ & $\begin{array}{l}\text { Esophagus biopsy } \\
\text { Oral cavity (swab) } \\
\text { Brushed esophagus } \\
\text { Brushed esophagus }\end{array}$ & $\begin{array}{l}04 / 29 / 99 \\
04 / 28 / 99 \\
04 / 29 / 99 \\
04 / 29 / 99\end{array}$ \\
\hline 3 & $\begin{array}{l}\text { C } 08 \\
\text { C } 09 \\
\text { C } 10\end{array}$ & $\begin{array}{l}\text { Esophagus biopsy } \\
\text { Brushed esophagus } \\
\text { Oral cavity (swab) }\end{array}$ & $\begin{array}{l}06 / 01 / 99 \\
06 / 01 / 99 \\
06 / 01 / 99\end{array}$ \\
\hline 4 & $\begin{array}{l}\text { D } 11 \\
\text { D } 12 \\
\text { D } 13 \\
\text { D } 14 \\
\text { D } 15 \\
\text { D } 16 \\
\text { D } 17 \\
\text { D } 18 \\
\text { D } 19\end{array}$ & $\begin{array}{l}\text { Esophagus biopsy } \\
\text { Esophagus biopsy } \\
\text { Brushed esophagus } \\
\text { Oral cavity (swab) } \\
\text { Oral cavity (swab) } \\
\text { Oral cavity (swab) } \\
\text { Brushed esophagus } \\
\text { Brushed esophagus } \\
\text { Esophagus biopsy }\end{array}$ & $\begin{array}{l}06 / 07 / 99 \\
05 / 21 / 99 \\
05 / 21 / 99 \\
05 / 21 / 99 \\
06 / 01 / 99 \\
06 / 07 / 99 \\
06 / 07 / 99 \\
06 / 07 / 99 \\
06 / 07 / 99\end{array}$ \\
\hline 5 & $\begin{array}{l}\text { E } 20 \\
\text { E } 21\end{array}$ & $\begin{array}{l}\text { Esophagus biopsy } \\
\text { Brushed esophagus }\end{array}$ & $\begin{array}{l}05 / 21 / 99 \\
05 / 21 / 99\end{array}$ \\
\hline 6 & $\begin{array}{l}\text { F } 22 \\
\text { F } 23 \\
\text { F } 24 \\
\text { F } 25 \\
\text { F } 26\end{array}$ & $\begin{array}{l}\text { Esophagus biopsy } \\
\text { Oral cavity (swab) } \\
\text { Brushed esophagus } \\
\text { Esophagus biopsy } \\
\text { Brushed esophagus }\end{array}$ & $\begin{array}{l}06 / 08 / 99 \\
06 / 08 / 99 \\
04 / 28 / 99 \\
04 / 28 / 99 \\
06 / 08 / 99\end{array}$ \\
\hline 7 & $\begin{array}{l}\text { G } 27 \\
\text { G } 28\end{array}$ & $\begin{array}{l}\text { Brushed esophagus } \\
\text { Esophagus biopsy }\end{array}$ & $\begin{array}{l}05 / 19 / 99 \\
05 / 21 / 99\end{array}$ \\
\hline 8 & $\begin{array}{l}\text { H } 29 \\
\text { H } 30\end{array}$ & $\begin{array}{l}\text { Esophagus biopsy } \\
\text { Brushed esophagus }\end{array}$ & $\begin{array}{l}05 / 19 / 99 \\
05 / 15 / 99\end{array}$ \\
\hline 9 & $\begin{array}{l}\text { I } 31 \\
\text { I } 32 \\
\text { I } 33\end{array}$ & $\begin{array}{l}\text { Oral cavity (swab) } \\
\text { Brushed esophagus } \\
\text { Esophagus biopsy }\end{array}$ & $\begin{array}{l}06 / 09 / 99 \\
06 / 09 / 99 \\
06 / 09 / 99\end{array}$ \\
\hline 10 & $\begin{array}{l}\text { J } 34 \\
\text { J } 35\end{array}$ & $\begin{array}{l}\text { Brushed esophagus } \\
\text { Esophagus biopsy }\end{array}$ & $\begin{array}{l}05 / 12 / 99 \\
05 / 12 / 99\end{array}$ \\
\hline 11 & $\begin{array}{l}\text { K } 36 \\
\text { K } 37\end{array}$ & $\begin{array}{l}\text { Brushed esophagus } \\
\text { Esophagus biopsy }\end{array}$ & $\begin{array}{l}05 / 12 / 99 \\
05 / 12 / 99\end{array}$ \\
\hline
\end{tabular}

$a$ : the letters refer to the initials of patients' names and the numbers to the order of application in the electrophoresis gel.

and can thus be taken as representative of the genome (Welsh \& McClelland 1990, Willians et al. 1990).

RAPD was used to analyse the genomic variability of the 37 isolates obtained from 11 immune-compromised patients infected with HIV. We were particularly interested in determining whether isolates from a specific body site or isolated from the same patient might be genetically more similar to each other than among isolates from a different body sites or different patients.

The yeast microflora of all patients had similar species, with exception of $C$. guilliermondii found just in the patient D, and genotypic diversities were found among the $C$. albicans isolates (Fig. 1a, b, c, d). Furthermore, a single patient can be colonized with multiple species or multiple genotypes of the same species at the same or different body sites, indicating that the yeast colonization is a dynamic process also in patients immune-suppressed with infection for HIV. This dynamic characteristic had been previously described (Xu et al. 1999a) for the yeast microflora of the vagina. The goal of this study was the contributions of two commonly recognized factors associated with candidiasis in women: HIV infection status and pregnancy.

This technique produced a profile of bands that allowed the identification of intra- and inter-specific polymorphisms among isolates obtained from the same pa- 


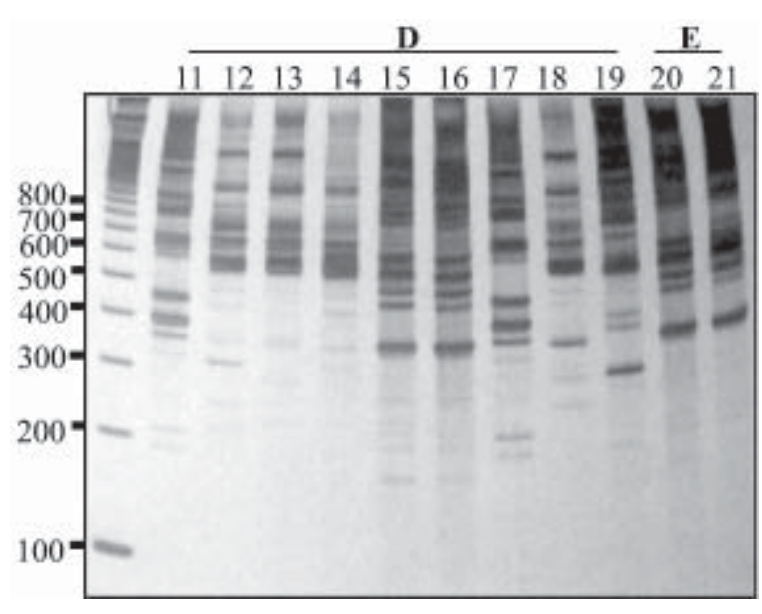

Fig. 2: randomly amplified polymorphic DNA profiles of 9 isolates from patient D (11-19) and 2 isolates from patient $\mathrm{E}$ (20-21), using $1 \mathrm{ng}$ of template and primer OPA 02 . The polymerase chain reaction products were resolved by electrophoresis on a $6 \%$ polyacrylamide gel followed by silver staining.
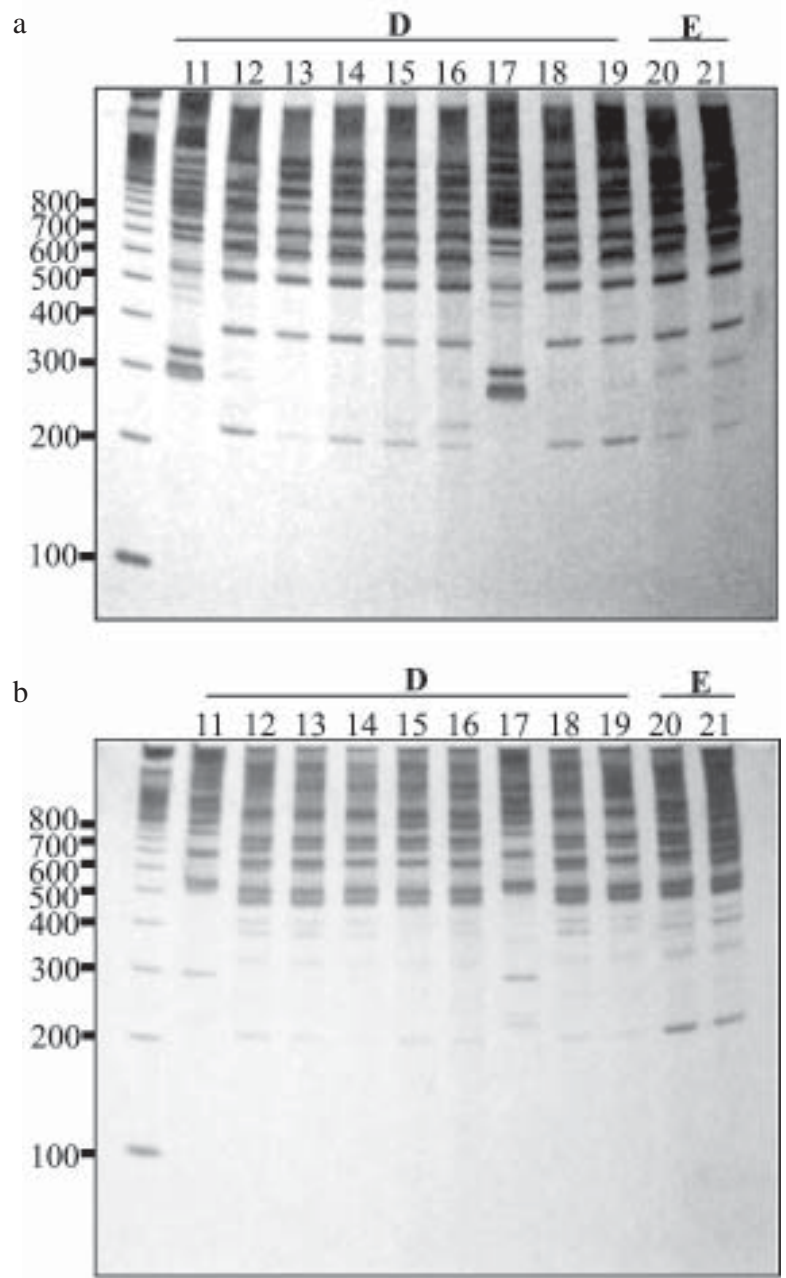

Fig. 3a: randomly amplified polymorphic DNA profiles of 9 isolates from patient D (11-19) and 2 isolates from patient $\mathrm{E}$ (20-21), using $1 \mathrm{ng}$ of template and primer OPA 03; b: analysis of further primer SOY with the same patients. The polymerase chain reaction products were resolved by electrophoresis on a $6 \%$ polyacrylamide gel followed by silver staining. tient. Additionally, it differentiates C. albicans strains isolated from different patients (Fig. 1b).

Fast and reliable identification of Candida genus species is important to define adequate therapeutic decisions, because the different species have highly variable susceptibilities to antifungal drugs. Accurate statistical records on case history and epidemiological studies also depend on effective identification. The traditional methods of identifying Candida species are often based on examination of phenotypic characteristics. This approach can be time-consuming, and the reliance on the variable expression of phenotypic characteristics can lead to inconsistent results.

In the present study, we could observe that RAPD technique was able to point out clearly the genomic variability within the Candida genus. The identification of specific species markers and the definition of larger details on these yeasts were important aspects that can aid in controlling and best understanding the epidemiology of the candidiasis.

The PCR genotyping has the advantage of being the least arduous procedure among the different typing methods, requiring only small amounts of DNA and being relatively easy to standardize among laboratories. It requires little knowledge of the molecular biology of the species being examined and no sequence information is necessary. In addition it is a quick, economical technique, with high reproducibility. It has been suggested that the use of a combination of different molecular typing procedures may help to distinguish certain isolates from one another (Pfaller et al. 1994).

According to the results obtained, RAPD assay can be considered an important tool to identify as well as study the inter- and intra-specific genetic variability among Candida genus isolates. Moreover, this technique allowed the identification of distinct strains related to different episodes of candidosis in HIV patients, which can be of great importance in the control and therapeutic choice.

\section{ACKNOWLEDGEMENTS}

To Dr Reynaldo Dietze, Dr Elenice Moreira Lemos, and Maristela Vicente Araújo from Infectious Diseases Center of Federal University of Espírito Santo for the collection of the HIV strains.

\section{REFERENCES}

Barchiesi F, Falconi Di Francesco L, Compagnucci P, Arzeni D, Cirioni O, Scalise G 1997. Genotypic identification of sequential Candida albicans isolates from AIDS patients by polymerase chain reaction techniques. Eur J Clin Microbiol Infect Dis 16: 601-605.

Bart-Delabesse E, Boiron P, Carlotti A, Dupont B 1993. Candida albicans genotyping studies with patients with AIDS developing resistance to fluconazole. J Clin Microbiol 31: 2933-2937.

Bart-Delabesse E, Van Deventer H, Goessens W, Poirot JL, Lioret N, Van Belkum A, Dromer F 1995. Contribution of molecular typing methods and antifungal susceptibility testing to the study of a candidemia cluster in a burn care unit. J Clin Microbiol 33: 3278-3283.

Caligiorne RB, Resende MA, Dias-Neto E, Oliveira SC, Azevedo V 1999. Dematiaceous fungal pathogens: analysis of ribosomal DNA gene polymorphism by polymerase chain reac- 
tion-restriction fragment length polymorphism. Mycoses 42: 609-614.

Cameron ML, Schell WA, Bruch S, Bartlett JA, Waskin HA, Perfect JR 1993. Correlation of in vitro fluconazole resistance of Candida isolates in relation to therapy and symptoms of individuals seropositive for human immunodeficiency virus type I. Antimicrob Agents Chemother 37: 24492453.

Clemons KV, Feroze F, Holmberg K, Stevens D 1997. Comparative analysis of genetic variability among Candida albicans isolates from different geographic locales by three genotypic methods. J Clin Microbiol 35: 1332-1336.

Clemons KV, Shankland GS, Richardson MD, Stevens DA 1991. Epidemiological study by DNA typing of Candida albicans outbreak in heroin addicts. J Clin Microbiol 29: 205-207.

Coleman DC, Bennett DE, Sullivan D, Gallagher PJ, Henman MC, Shanley DB, Russell RJ 1993. Oral Candida in HIV infection and AIDS: new perspectives/new approaches. Crit Rev Microbiol 19: 61-82.

Coleman D, Sullivan D, Haynes K, Henman M, Shanley D, Bennett D, Moran G, McCreary C, O'Neill L, Harrington B 1997. Molecular and phenotypic analysis of Candida dubliniensis: a recently identified species linked with oral candidosis in HIV-infected and AIDS patients. Oral Dis 3(Suppl.1): S96-S101.

Corlotti A, Chaib F, Couble A, Bourgeois N, Blanchard V, Villard J 1997. Rapid identification and fingerprinting of Candida krusei by PCR-based amplification of the species-specific repetitive polymorphic sequence CKRS-1. J Clin Microbiol 35: 1337-1343.

Diaz-Guerra TM, Martinez-Suarez JV, Laguna F, RodriguezTudela JL 1997. Comparison of four molecular typing methods for evaluating genetic diversity among Candida albicans isolates from human immunodeficiency virus-positive patients with oral candidiasis. J Clin Microbiol 35: 856-861.

Espinel-Ingroff A, Vazquez JA, Boikov D, Pfaller MA 1999. Evaluation of DNA-based typing procedures for strain categorization of Candida spp. Diagn Microbiol Infect Dis 33: 231-239.

Hazen K 1995. New and emerging yeast pathogens. Clin Microbiol Rev 8: 462-478.

Heimdahl A, Nord CK 1990. Oral yeast infections in immunocompromised and seriously diseased patients. Acta Odontol Scand 48: 77-84.

Holmes AR, Cannon RD, Shepherd MG, Jenkinson HF 1994. Detection of Candida albicans and other yeasts in blood by PCR. J Clin Microbiol 32: 228-231.

Klein RS, Harris CA, Butkus Small C, Moll B, Lesser M, Friedland GH 1984. Oral candidiasis in high risk patients as the initial manifestation of the acquired immunodeficiency syndrome. N Engl J Med 311: 354-358.

Kreger-Van Rij NJW 1984. The Yeasts, a Taxonomic Study, 3rd ed., Elsevier, Amsterdam, 1081 pp.

Kurtzman CP, Fell JW 1998. The Yeast, a Taxonomic Study, 4th ed., Elsevier, Amsterdam, Lausanne, New York, Oxford, Shannon, Singapure, Tokio, $420 \mathrm{pp}$.

Lehmann PF, Lin D, Lasker BA 1992. Genotypic identification and characterization of species and strains within the genus Candida by using random amplified polymorphic DNA. $J$ Clin Microbiol 30: 3249-3254.

Merz WG 1990. Candida albicans strain delineation. Clin Microbiol Rev 3: 321-334.

Meyer W, Latouche GN, Daniel HM, Thanos M, Mitchell TG, Yarrow D, Schonian G, Sorrell TC 1997. Identification of pathogenic yeasts of the imperfect genus Candida by polymerase chain reaction fingerprinting. Electrophoresis18: $1548-1559$.
Miyakawa Y, Mabuchi T, Fukazawa Y 1993. New method for detection of Candida albicans in human blood by polymerase chain reaction. J Clin Microbiol 31: 3344-3347.

Odds FC 1988. Pathogenesis of candidosis. In FC Odds, Candida and Candidosis, Bailliere Tindall, London, p. 252278.

Odds FC, Brawner DL, Staudinger J, Magee PT, Soll DR 1992. Typing of Candida albicans strains. J Med Vet Mycol 30 (Suppl.): 87-94.

Odds FC, Schmid J, Soll DR 1990. Epidemiology of Candida infections in AIDS. In H Vanden Bossche, DWR Mackenzie, G Cauwenbergh, J Van Cutsem, E Drouhet, B Dupont (eds), Mycoses in AIDS Patients, Plenum Press, New York, p. 6774.

Pfaller MA 1995. Epidemiology of candidiasis. J Hosp Infect 30 (Suppl.): 329-338.

Pfaller MA, Cabezudo I, Hollis R, Huston B, Wenzel RP 1990. The use of biotyping and DNA fingerprinting in typing Candida albicans from hospitalized patients. Diagn Microbiol Infect Dis 13: 481-489.

Pfaller MA, Messer SA, Hollis RJ 1994. Strain delineation and antifungal susceptibilites of epidemiologically related and unrelated isolates of Candida lusitaniae. Diagn Microbiol Infect Dis 20: 127-133.

Robert F, Lebreton F, Bougnoux ME, Paugam A, Wassermann D, Schlotterer M, Tourte-Schaffer C, Dupouy-Camet J 1995. Use of random amplified polymorphic DNA as a typing method for Candida albicans in epidemiological surveillance of a Burn Unit. J Clin Microbiol 33: 23662371.

Romano F, Ribeira G, Giuliano M 1994. A study of a hospital cluster of systemic candidosis using DNA typing methods. Epidemiol Infect 112: 393-398.

Samaranayake LP, Holmstrup P 1989. Oral candidiasis and human immunodeficiency virus infection. J Oral Pathol Med 18: 554-564.

Santos FR, Pena SD, Epplen JT 1993. Genetic and populational study of an Y-linked tetranucleotide repeat DNA polymorphism. Hum Genet 90: 655-656.

Scher S, Stevens A 1988. A Candida albicans dispersed, repeated gene family and its epidemiological applications. Proc Natl Acad Sci USA 85: 1452-1456.

Schmid J, Voss E, Soll DR 1990. Computer-assisted methods for assessing strain relatedness in Candida albicans by fingerprinting with the moderately repetitive sequence Ca3. $J$ Clin Microbiol 28: 1236-1243.

Stevens DA, Odds FC, Scherer S 1990. Application of DNA typing methods to Candida albicans epidemiology and correlations with phenotype. Rev Infect Dis 12: 258-266.

Voss A, Pfaller MA, Hollis RJ, Rhine-Chalberg J, Doebbeling BN 1995. Investigation of Candida albicans transmission in a surgical intensive care unit cluster by using genomic DNA typing methods. J Clin Microbiol 33: 576-580.

Welsh J, Mc Clelland M 1990. Fingerprinting genomes using PCR with arbitrary primers. Nucl Acids Res 18: 7213-7218.

Willians JGK, Kubelick AR, Livak KJ, Rafalski JA, Tingey SV 1990. DNA polymorphisms amplified by arbitrary primers are useful as genetic markers. Nucl Acids Res 18: 65316535.

Xu J, Boyd CM, Livingston E, Meyer W, Madden JF, Mitchell TG 1999a. Species and genotypic diversities and similarities of pathogenic yeast colonizing women. J Clin Microbiol 37: 3835-3843.

Xu J, Vilgalys R, Mitchell TG 1999b. Lack of genetic differentiation between two geographic samples of Candida albicans isolated from patients infected with human immunodeficiency virus. J Bacteriol 181: 1369-1373. 